\title{
Performance measures and metrics in a supply chain environment
}

\author{
Thi Tam Le $\mathrm{a}^{*}$
}

${ }^{a}$ Thuyloi University, 175 Tay Son, Dong Da, Ha Noi, Vietnam

\begin{tabular}{l}
\hline C H R O N I C L E \\
\hline Article history: \\
Received July 14, 2019 \\
Received in revised format July \\
28,2019 \\
Accepted August 52019 \\
Available online \\
August 52019 \\
\hline Keywords: \\
Environmental Management \\
Accounting \\
Environmental Efficiency \\
Financial Efficiency \\
Sustainable Supply Chain \\
Management
\end{tabular}

\section{A B S T R A C T}

\begin{abstract}
This paper investigates the role of environmental management accounting on sustainable supply chain management and the link between sustainable supply chain management and efficiency including financial and environmental factors using questionnaire-based survey. The study designed and sent questionnaires to 600 construction material manufacturing enterprises in Vietnam and managed to collect 418 valid ones which was processed by SPSS 20.0 software. The results show that environmental management accounting had a significantly positive impact on sustainable supply chain management. Therefore, if enterprises adopt environmental management accounting, they will more likely implement sustainable supply chain management more efficiently. On the other hand, the findings point out that sustainable supply chain management positively affect to both financial and environmental efficiency. Finally, the study provides some sound suggestions to Vietnamese construction materials manufacturing industry.
\end{abstract}

(c) 2020 by the authors; licensee Growing Science, Canada.

\section{Introduction}

Sustainable development is always the top priority of countries in general and of businesses in particular. This target is strongly promoted from governments, customers and stakeholders. Many studies have affirmed that environmental and social affairs have appeared in the supply chain (Burritt, 2002; Burritt et al. 2011). As environmental pressures increase, companies in supply chain must be transparent about the environmental impacts on the products and production processes as well as assess and improve the effectiveness of those impacts. The best solution for the problems is to set up accounting standards and accounting information systems appropriately and effectively in supply chain.

Construction material manufacturing industry is one of the strong economic sectors of the national economy, playing an important role in the socio-economic development and investment in infrastructure construction. For Vietnam, a country that is implementing the process of industrializing the economy from a backward agricultural country, the role of the construction materials industry is even more important. Infrastructure construction is a top priority and is a prerequisite for industrialization. Sustainable supply chain management (SSCM) brings significant potentials for industry in general and construction materials industry in particularly such as credibility of customers, market dominance, ability to reach out of businesses; the competitiveness of enterprises, economic efficiency improvement. SSCM has been applied during the past two decades (Seuring và Muller,

* Corresponding author Tel. +849537282

E-mail address: lethitam@tlu.edu.vn (T.T. Le)

C 2020 by the authors; licensee Growing Science. doi: $10.5267 /$ j.uscm.2019.8.003 
2008). In Vietnam, there is sadly lack of understanding about SSCM in manufacturing firms. Although documents on SSCM have been strongly growing over the years, the accounting aspect is not the central issue of these documents. Very few authors mentioned the role of environmental management accounting (EMA) in sustainable supply chain management as well as the impact of SSCM on environmental and financial performance. According to Burritt (2011), EMA has been contributing to accounting and management literature for 20 years. Yet EMA's contributions to supply chain management are missing from prior literatures. Therefore, the research on the relationship between EMA, SSCM and eco-efficiency has filled the research gap. The two main subjects in the study are to examine the role of EMA in SSCM and the relationship between SSCM and enterprises' performance including environmental and financial sectors.

\section{Research Overview}

\subsection{EMA and Sustainable supply chain management}

The term "sustainable" indicates a more comprehensive view of environmental, social and economic impacts. SSCM is an emerging concept that is fueled by environmental concerns from many stakeholders. Customer demand and government pressure continue motivating companies more and more sustainable (Guide Jr \& Srivastava, 1998). As a result, government requirements and community expectations for environmental accountability put pressure on companies in supply chain to develop strategic planning bringing several green concepts. The studies of SSCM increased significantly last 15 years (Seuring và Muller, 2008). Different possible reasons are examined which explain why SSCM appears to be of growing importance to companies including: globalization; cost-effective logistics processes; market-pull; information systems (Burritt, 2011).

The tools of EMA applied in the supply chain are expressed in voluntary international standards such as ISO 14051 and ISO 14052. While ISO 14051 extends material flow cost accounting method (MFCA) in managing both upstream and downstream supply chain collaborations, ISO 14052 provides more specific guidelines for practicing in broader supply chain settings (Christ, 2017). Kokubu and Tachikawa (2011) introduced MFCA into 50 supply chains between 2008 and 2011 in Japan aimed at illustrating how significant material wastes in supplier operations are often transferred to purchasers. MFCA highlights numerous benefits to supply chain settings such as building waste management and control system along supply chain.

Thanks to sustainable supply chain, successful management requires not only high quality environmental and financial performance, but also their integration (Boyd et al., 2007). However, it is significantly restrict the relationship between supply chain management and the economic and environmental dimensions (Linton et al., 2007; Vlachos et al., 2007). The characteristics of sustainability which is sadly lacking from much of the earlier literatures (Burritt, 2011). According to Seuring and Muller (2008), one of the incentives to achieve SSCM is to encourage focal companies to push their suppliers in take-up of and compliance with standards of environmental management. Therefore, it is necessary to understand the managerial requirements for EMA to support SSCM. As a result, supply chain management make pressures to hold companies responsible for their environmental, social and financial performance, not just in their own but along the whole supply chain and in the light of expectations from customers, regulators and other stakeholders (Seuring \& Muller, 2008). Focal companies need to have environmental responsibility and help other companies in supply chain to comply environmental standards. It is realized that a company, a part from supply chain lacks environmental responsibility that impacts on sustainable products. Reputation of the focal companies can collapse and others in supply chain suffer high risks requiring that environmental strategy safeguards against high risks (Burritt et al., 2011). The strategy will be interaction EMA with SSCM and performance. EMA is an important tool to provide complete information for establishing sustainable supply chain decisions. Because if companies aimed at improving sustainable supply chain, not only economic information but also environmental information about the supply chain are required (Burritt et al., 2002; Viere et al., 2011). According to Schaltegger (2013), with accounting for ecoefficiency, EMA supplies the methods to support for sustainable supply chain goal. EMA can help to 
gain more efficient design, production or logistical operations between partners in supply chain (Burritt et al., 2011). Viere et al. (2011) apply EMA methods to determine the stages in the coffee supply chain that have the highest environmental impacts and the most optimal solutions selected for environmental improvement. Cultivation and consumption are the two most important stages from an environmental concept. Environmental concerns will directly affect financial performance. For example, using inefficient energy or using too much fertilizers will reduce the profitability of the overall supply chain or less competitive market prices.

Table 1

The role of EMA in sustainable supply chain management

\begin{tabular}{llll}
\hline \multicolumn{1}{c}{ Short-term } & \multicolumn{1}{c}{ Long-term } & \multicolumn{1}{c}{ Short-term } & \multicolumn{1}{c}{ Long-term } \\
\hline Sustainable Purchase & Sustainable Purchase & Sustainable Purchase & \multicolumn{1}{c}{ Sustainable Purchase } \\
Risk analysis process & Risk analysis process & Risk analysis process & Risk analysis process \\
Social impact & Social impact measurement & Social impact & Social impact \\
measurement & Carbon Accounting & measurement & measurement \\
Carbon Accounting & Macro-Micro link & Carbon Accounting & Carbon Accounting \\
Macro-Micro link & Stakeholder engagement & Macro-Micro link & Macro-Micro link \\
Stakeholder engagement & Sustainable management & Stakeholder engagement & Stakeholder engagement \\
Sustainable management & control & Sustainable management & Sustainable management \\
control & Supply chain & control & control \\
Supply chain & International assessments & Supply chain & Supply chain \\
Environmental benefits & CRS competitiveness & International assessments & International \\
& Environmental capital & Environmental capital & Assessments \\
& investment & investment & CRS competitiveness \\
& Cost - benefit analysis & Environmental benefits & Environmental capital \\
& & & investment \\
& & & Cost - benefit analysis \\
\hline
\end{tabular}

Supply chain management by large companies such as IBM, Otto Group and Wal-Mart is stimulated towards the development of EMA (Schaltegger \& Burritt, 2000). EMA is the useful tool to gather, classify, record and exchange environmental information so that companies in supply chain can show their sustainability credentials in order to maintain and build their businesses. As a result, environmental and financial performance in companies are improved.

The relationship between EMA and SSCM can be manifested in many ways (Burritt, 2011) including: firstly, application of the EMA support sustainable supply chain management requiring the interaction between partners along the supply chain to agree on the goals and the sharing benefits and costs. Secondly, EMA should be viewed as a supported tool to strengthen partnerships in its network as well as compete with other supply chains. Finally, EMA in supply chain management can help to increase eco-efficiency through cost savings and revenue improvement throughout the value chain. EMA encourages carbon emission reduction, cleaner production processes, sustainable movement and logistics transportation, termination of product life waste reduction, recycling and reuse as highlighted by Kreuze and Newell (1994) using life cycle accounting (LCA). LCA is an attempt to identify all environmental costs (internal and external) related to products, processes and operations through life cycle stages. The life cycle stages of the product includes material selection, production, use, reuse, maintenance, recycling and waste management (Kreuze \& Newell, 1994; Parker, 2000). LCA helps decision makers prioritize options for environmental improvements of the supply chain (Salomone, 2003).

From the above explanations, it is argued that:

$H_{1}$ : EMA has a significant impact on sustainable supply chain management (SSCM).

\subsection{Sustainable supply chain management and Eco- efficiency}

Eco-efficiency is to minimize environmental impacts while maximizing production efficiency (Mutingi, 2013). Companies realize that it is necessary to upgrade supply chain management in a 
sustainable way to comply with current environmental laws and maintain a long-term competitive advantage through technology innovation and eco-efficiency improvements (Baines et al., 2012). The central goals of SSCM are primarily focused on those process operations that impacts on environmental efficiency such as minimization of waste, optimize resource usage (Mutingi, 2013). As a result, companies in supply chain save costs and improve profits.

According to Viere (2011), SSCM is applied to increase eco-efficiency by using efficient quantity of fertilizers. Eco-efficiency is shared with three members in coffee supply chain who do coffee faming, coffee processing and coffee refinement. With constant revenue, the profit of three members will increase sustainably by reducing environmental impacts through the effective use of fertilizers.

SSCM practices are increasingly recognized as systematic and comprehensive mechanisms to achieve environmental efficiency (Green et al., 2012; Lai \& Wong, 2012; Zhu et al., 2010). SSCM helps reduce environmental impacts because members in supply chain identify environmental issues and share together. The positive relationship between SSCM and environmental efficiency is initially pointed out by Zailani et al. (2012). They realize that the implementation of sustainable packaging had a significant positive effect on environmental performance, especially due to environmental cooperation with customers. Therefore, the next hypothesis is developed:

$\mathrm{H}_{2}$ : SSCM has a significant impact on financial efficiency.

The implementation of SSCM can reduce production costs, improve product value, increase image for organizations and achieve competitive advantage (Porter \& Van der Linde, 1995; Hart \& Ahuja, 1996; Hart, 1997). SSCM practices also have the ability to reduce costs in the long run due to efficient use of materials and energy. Reducing costs and increasing revenue is the result of improved financial performance. Many studies conclude that SSCM practice leads to expand organizational performance including financial sector (Lee et al., 2012; Green et al., 2012, Ochieng, 2016). Therefore, manufacturing firms should implement sound environmental practices in all stages of the supply chain which is likely to perform better financially. Thus, the following hypothesis is proposed:

$H_{3}$ : SSCM has a significant impact on environmental efficiency.

\section{Research methodology and model}

The study was conducted to investigate the role of EMA in SSCM and the connection of SSCM to environmental and financial efficiency. Therefore, quantitative research method through survey is used to solve the above research objectives. Material production enterprises with medium and large scale in Vietnam are selected in the scope of research. Because medium and large sized enterprises are able to implement of EMA while small sized enterprises do not fully adopt and have no understanding of the EMA. Furthermore, with complex supply chains need to secure the consistency of data they receive by their suppliers, and need instruments for a meaningful interpretation of this data. Construction materials industry is considered as one of the sectors that contribute greatly to the economic development of Vietnam at the same time cause negative impacts on the environment. Every year the construction materials industry generates emissions and toxic dust affecting the living environment and people. Therefore, it is necessary to manage and control environmental issues in construction materials supply chain. The author sent survey forms to 600 construction material enterprises in the period of June 2018 - January 2019. The survey results obtained 435 votes, in which, 17 questionnaires were removed from research due to incomplete, biased issues, 418 valid questionnaires were retained. Valid votes will be numbered, entered and processed by SPSS 20.0 software. Based on the above literature discussions, the research model is developed.

EMA application (EMA): There are ten (10) scales of EMA application. Ten scales is modified and adapted from many previous studies such as Hyršlová and Hájek (2005); Ramli and Ismail (2013); Jamil et al. (2015); Jinadu et al. (2015), Kokubu and Nashioka (2005); Jalaludin et al. (2011), Le \& Nguyen (2018). A five point scale (where $1=$ no application, $5=$ full application) is used for EMA variable. 
Sustainable supply chain management (SSCM): The six scales of SSCM are measured by Seuring \& Muller (2008), Vachon \& Klassen (2008), Zhu et al. (2010) including: Legal requirements and command-and-control regulations; Compliance with codes of environmental management and social responsibility; Internal risk management; cross-functional cooperation for environmental improvement; building environmental collaboration with upstream suppliers and downstream customers; and sending environmental requirement to suppliers. SSCM uses a five point Likert scale with $1=$ no implement and $5=$ full implement.

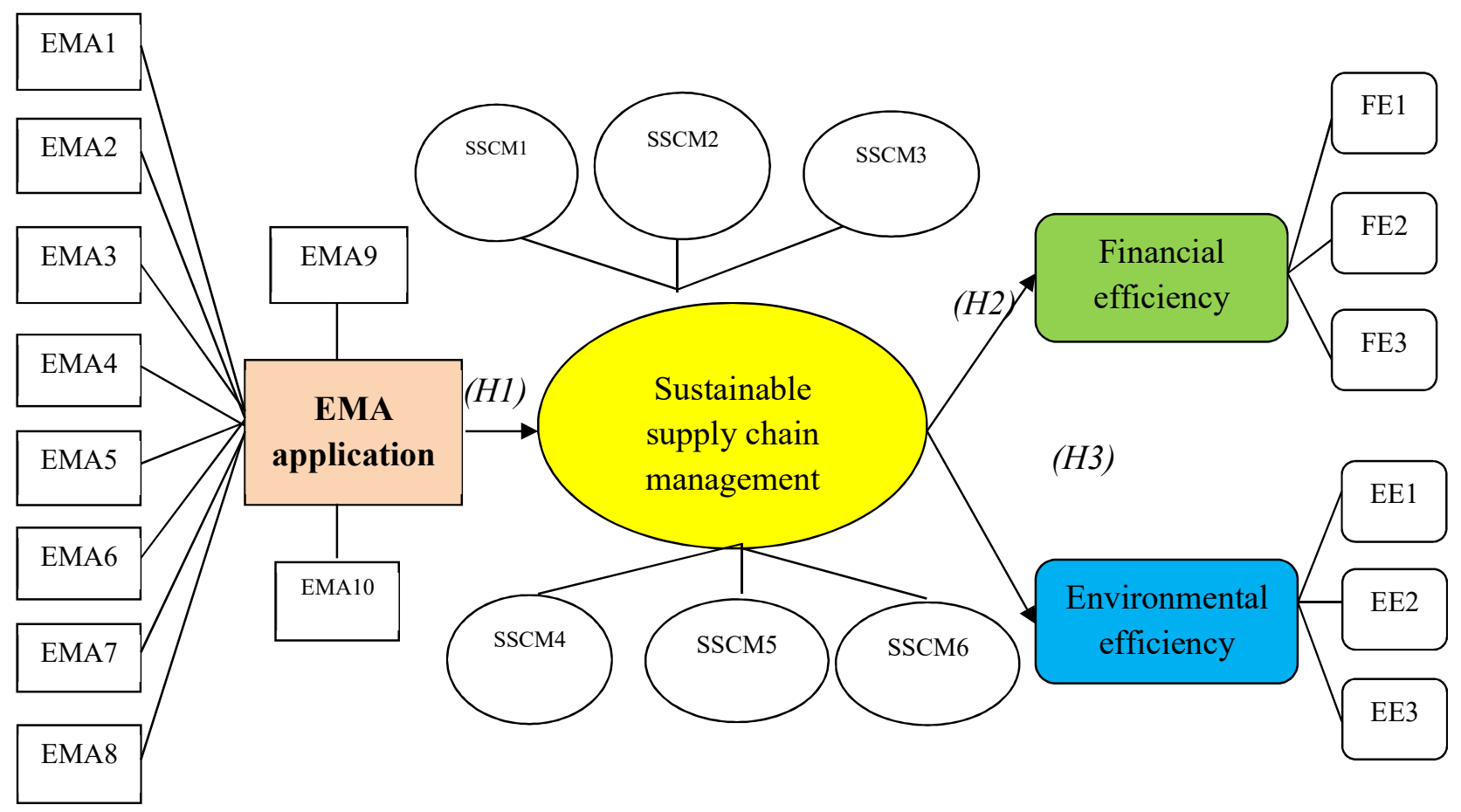

Fig. 1. Research model

Financial efficiency $(F E)$ : The study uses three scales to measure financial efficiency consisting of Return on Assets (ROA), Return on Equities (ROE) and Return on Sales (ROS) supported by Hart \& Ahuja (1996), Konar \& Cohen (2001) and Iwata and Okada (2010). In which, ROA is the most popular scale. According to Qian (2012), ROA is considered a suitable scale reflecting financial efficiency in many previous studies (Russo \& Fouts, 1997; King \& Lenox, 2002; Nakao et al., 2007; Ong et al., 2014). ROA is a common measure used in many studies and a representative indicator of financial efficiency (Ten, 2005). In addition, Wagner et al. (2002) confirm that two criteria of ROE and ROS used measure financial activities in the paper manufacturing industry in Europe. Some people used ROA and ROS to examine the relationship between how environmental activities affect financial performance (cited in Iwata \& Okada, 2010).

Environmental efficiency (EE): The study inherits the scales of Qian (2012), Tuwaijri et al. (2003); Earnhart \& Lizal (2010); Ong et al. (2014), Itawa \& Okada (2010). They used three scales including the amount of wastes generated, environmentally friendly products, image and reputation. The scale "the amount of wastes generated" is most commonly used. Tuwaijri et al. (2003) point out that this scale relates to the first three principles of environmental performance issued by CERES: minimizing environmental impacts, using efficient resources and reducing wastes. Qian (2012) concur that amount of wastes generated, environmentally friendly products, image and reputation are indicators of environmental performance that is supported by the studies such as Konar \& Cohen (1997), Konar \& Cohen (2001), Earnhart \& Lizal (2006), Khanna \& Damon (1999), Khanna et al. (1998), Arora \& Cason (1995), Itawa \& Okada (2010). Respondents are asked to evaluate financial and environmental efficiency relative to the main competitors over the last 3 years. The efficiency indicators are measured 
using a five point Likert scale (rang from 1 = much worse than competitors" to 5 "much better than competitors".

\section{The results}

\subsection{Testing the reliability of the scales}

According to Hari et al. (2006), Cronbach alpha coefficient is evaluated according to the following rule: The scales of total variables are acceptable when Cronbach alpha coefficients are greater than 0.6. In table 2, Cronbach's Alpha coefficients of four total variables are greater than 0.8 , so the scales are highly reliable.

Table 2

Testing the reliability of total variables

\begin{tabular}{lccc}
\hline & Cronbach's Alpha & Cronbach's Alpha Based on Standardized Items & N of Items \\
\hline EMA & 0.919 & 0.916 & 10 \\
SSCM & 0.885 & 0.885 & 6 \\
FE & 0.931 & 0.931 & 3 \\
EE & 0.911 & 0.911 & 3 \\
\hline
\end{tabular}

Corrected Item-Total Correlation coefficient indicates the degree of association between a basic scale in the total variable and the remaining scales. It reflects the contribution level of a particular scale to the total variable. The standard for evaluating whether a scale actually contributes value to a total variable is that Corrected Item-Total Correlation coefficient is greater than 0.3 and Cronbach's Alpha if Item Deleted coefficient is greater than 0.6. Table 3 presents that all scales ensure the above standards.

Table 3

Testing the reliability of the scales

\begin{tabular}{ccccc}
\hline & $\begin{array}{c}\text { Scale Mean if Item } \\
\text { Deleted }\end{array}$ & $\begin{array}{c}\text { Scale Variance if } \\
\text { Item Deleted }\end{array}$ & $\begin{array}{c}\text { Corrected Item-Total } \\
\text { Correlation }\end{array}$ & $\begin{array}{c}\text { Cronbach's Alpha if Item } \\
\text { Deleted }\end{array}$ \\
\hline EMA1 & 18.70 & 33.213 & .727 & .909 \\
EMA2 & 19.20 & 35.091 & .620 & .915 \\
EMA3 & 19.40 & 35.536 & .620 & .915 \\
EMA4 & 19.62 & 38.414 & .383 & .906 \\
EMA5 & 19.05 & 32.710 & .832 & .903 \\
EMA6 & 19.18 & 33.745 & .717 & .911 \\
EMA7 & 19.20 & 34.892 & .727 & .910 \\
EMA8 & 19.03 & 32.546 & .832 & .903 \\
EMA9 & 18.95 & 33.928 & .695 & .908 \\
EMA10 & 19.04 & 32.540 & .783 & .883 \\
SSCM1 & 15.46 & 12.120 & .586 & .877 \\
SSCM2 & 15.67 & 12.218 & .621 & .844 \\
SSCM3 & 15.31 & 10.702 & .817 & .868 \\
SSCM4 & 15.44 & 11.365 & .681 & .866 \\
SSCM5 & 15.46 & 12.023 & .696 & .848 \\
SSCM6 & 15.29 & 10.715 & .795 & .897 \\
FE1 & 6.28 & 5.066 & .861 & .901 \\
FE2 & 6.17 & 5.152 & .855 & .900 \\
FE3 & 6.14 & 5.322 & .857 & .856 \\
EE1 & 6.53 & 4.461 & .843 & .845 \\
EE2 & 6.41 & 4.636 & .867 & .922 \\
EE3 & 6.85 & 3.815 & .787 & \\
\hline
\end{tabular}

\subsection{Descriptive statistics}

Table 4 displays the results of descriptive statistics about the scales. The values of Skewness and Kurtosis of all observed variables in $[-2 ; 2]$ so the observed variables are acceptable in standard distribution (George \& Mallery, 2010). 
Table 4

Descriptive statistics

\begin{tabular}{|c|c|c|c|c|c|}
\hline & Mean & Median & Mode & Skewness & Kurtosis \\
\hline EMA1 & 2.56 & 3.00 & 3 & -.049 & -.871 \\
\hline EMA2 & 2.06 & 2.00 & 2 & .331 & -.606 \\
\hline EMA3 & 1.86 & 2.00 & 2 & .586 & -.218 \\
\hline EMA4 & 1.64 & 2.00 & 2 & .563 & -.404 \\
\hline EMA5 & 2.22 & 2.00 & 2 & .309 & -.621 \\
\hline EMA6 & 2.08 & 2.00 & 2 & .478 & -.495 \\
\hline EMA7 & 2.07 & 2.00 & 2 & .195 & -.515 \\
\hline EMA8 & 2.23 & 2.00 & 2 & .388 & -.570 \\
\hline EMA9 & 2.31 & 2.00 & 2 & .164 & -.719 \\
\hline EMA10 & 2.15 & 2.00 & 2 & .427 & -.695 \\
\hline EMAA & 2.1263 & 2.1000 & 2.00 & .225 & -.666 \\
\hline SSCM1 & 3.06 & 3.00 & 3 & .331 & -.606 \\
\hline SSCM2 & 2.86 & 3.00 & 3 & .586 & -.218 \\
\hline SSCM3 & 3.22 & 3.00 & 3 & .309 & -.621 \\
\hline SSCM4 & 3.08 & 3.00 & 3 & .478 & -.495 \\
\hline SSCM5 & 3.07 & 3.00 & 3 & .195 & -.515 \\
\hline SSCM6 & 3.23 & 3.00 & 3 & .388 & -.570 \\
\hline SSCM & 3.0873 & 3.0000 & 3.00 & .310 & -.528 \\
\hline FE1 & 3.01 & 3.00 & 2 & .149 & -1.095 \\
\hline FE2 & 3.13 & 3.00 & 2 & .032 & -1.084 \\
\hline FE3 & 3.15 & 3.00 & 2 & .068 & -1.049 \\
\hline FE & 3.0989 & 3.0000 & 2.00 & .099 & -1.357 \\
\hline EE1 & 3.37 & 3.00 & 3 & .175 & -1.051 \\
\hline EE2 & 3.49 & 3.00 & 3 & -.044 & -.760 \\
\hline EE3 & 3.04 & 3.00 & 4 & -.052 & -1.174 \\
\hline EE & 3.2982 & 3.0000 & 4.00 & .082 & -1.284 \\
\hline
\end{tabular}

EMA variable: The scales receive mean values by 2.1263. In which, two variables including EMA1 "Using environmental monetary information", EMA 9 "Estimating environmental information" have the largest mean value (respectively 2.56, 2.31), two variables such as EMA4 "Tracking detailed environmental accounts", EMA7 "Developing environmental performance indicators" have the lowest mean value. On the other hand, mean value of scales is in the range from 1.97 to 2.68 , their mode values are equal to 2, excepting variable EMA1 with mode value by 3. It reflects the fact that construction materials manufacturing enterprises apply ECMA in a low level.

SSCM variable: The average value of SSCM variable is by 3,0873 indicating that sustainable supply chain management in the construction materials industry is not highly evaluated. The SSCM6 scale "Compliance with codes of environmental management and social responsibility" has the largest mean value of 3.23 while the SSCM2 scale "building environmental collaboration with upstream suppliers and downstream customers" has the lowest value of 2.86. FE variable: The average value of this variable is 3.0989 . As a result, financial efficiency in the industry compared with main competitors is not high. In which the scale "ROS" rates at the highest level of 3.15.

EE variable: FE variable has the mean value of 3.2982 addressing that the environmental efficiency in construction materials industry is at average level when comparing with the competitors in last 3 years. The scale EF3 "Image and reputation" has largest value of 3.49.

In general, although the construction materials industry has made a great contribution to the Vietnamese economy, the enterprises do not popularly practice EMA. The reason for this result can come from many sides such as lack of government pressure, stakeholder pressure, commitment of corporate governance, etc. (Le \& Nguyen, 2018). Moreover, SSCM is not strongly paid attention by construction materials industry. Perhaps the enterprises more focus on financial efficiency (shortterm benefits) in stead of sustainable performance (long-term benefits). 


\subsection{Regression analysis}

In regression analysis, three hypotheses $\mathrm{H}_{1}, \mathrm{H}_{2}, \mathrm{H}_{3}$ are presented corresponding to three models 1,2,3. In Table 5, the $\mathrm{R}$ correlation coefficient indicates the relationship between two variables in the regression model. The first model shows that Adjusted $\mathrm{R}^{2}$ is by 0.866 which confirm the close and positive relationship between EMA and SSCM. Therefore, the change in the EMA explains $86.6 \%$ of the change of SSCM. In the remaining two model, Adjusted $\mathrm{R}^{2}$ is by 0.485 and 0.449 (less than 0.5 ) which find that the relationship between SSCM and FE, EF is not strictly. In addition, the value of d of Durbin - Watson test in three models less than 2 showing there is no similarity between the remainder in the regression model.

Table 5

Model Summary

\begin{tabular}{cccccc}
\hline Model & R & R Square & Adjusted R Square & Std. Error of the Estimate & Durbin-Watson \\
\hline 1 & $.883^{\mathrm{a}}$ & .866 & .866 & .11930 & 1.923 \\
2 & $.697^{\mathrm{a}}$ & .485 & .484 & .80372 & .875 \\
3 & $.670^{\mathrm{a}}$ & .449 & .448 & .75392 & .758 \\
\hline
\end{tabular}

Table 6 examines the significance of $\mathrm{R}^{2}$ coefficient for the whole, which is used to evaluate the suitability of the model. Sig. values in the ANOVA table of the three model are equal to 0.000 , less than 0.05 , meaning that $\mathrm{R}^{2}$ is really different from zero, or the regression model is really meaningful. Hypotheses H1, H2, H3 are accepted.

Table 6

Testing the suitability of three hypothesis using ANOVA test

\begin{tabular}{llccccc}
\hline Model & & Sum of Squares & df & Mean Square & F & Sig. \\
\hline 1 & Regression & 168.889 & 1 & 168.889 & 11865.724 & .000 \\
& Residual & 5.921 & 416 & .014 & & \\
& Total & 174.811 & 417 & & & .000 \\
& Regression & 253.189 & 1 & 253.189 & 391.952 & \\
& Residual & 268.724 & 416 & .646 & & .000 \\
& Total & 521.913 & 417 & & & \\
& Regression & 193.033 & 1 & 193.033 & 339.611 & \\
& Residual & 236.452 & 416 & .568 & & \\
& Total & 429.485 & 417 & & & \\
\end{tabular}

Table 7

Regression model

\begin{tabular}{|c|c|c|c|c|c|c|c|c|}
\hline & \multirow[t]{2}{*}{ Model } & \multicolumn{2}{|c|}{$\begin{array}{l}\text { Unstandardized } \\
\text { Coefficients }\end{array}$} & \multirow{2}{*}{$\begin{array}{c}\begin{array}{c}\text { Standardized } \\
\text { Coefficients }\end{array} \\
\text { Beta } \\
\end{array}$} & \multirow[t]{2}{*}{$\mathrm{t}$} & \multirow[t]{2}{*}{ Sig. } & \multicolumn{2}{|c|}{$\begin{array}{l}95.0 \% \text { Confidence Interval } \\
\text { for B }\end{array}$} \\
\hline & & $\mathrm{B}$ & Std. Error & & & & Lower Bound & Upper Bound \\
\hline \multirow{2}{*}{1} & Constant & .921 & .021 & & 44.274 & .000 & .880 & .961 \\
\hline & EMA & 1.019 & .009 & .983 & 108.930 & .000 & 1.001 & 1.037 \\
\hline \multirow{2}{*}{2} & Constant & -.485 & .185 & & -2.618 & .009 & -.849 & -.121 \\
\hline & SSCM & 1.161 & .059 & .697 & 19.798 & .000 & 1.046 & 1.276 \\
\hline \multirow{2}{*}{3} & Constant & .169 & .174 & & .973 & .331 & -.173 & .511 \\
\hline & SSCM & 1.014 & .055 & .670 & 18.429 & .000 & .905 & 1.122 \\
\hline
\end{tabular}

Table 7 shows the values of the coefficients in three regression equations. In model 1 , constant coefficient has the value of 0.921 . This coefficient indicates the influence of other factors without EMA variable to SSCM. The beta coefficient corresponding to EMA variable receives the value of 1.019 reflecting that when EMA increase of 1 unit, SSCM increases of 1.019 units. In addition, Values of Sig. is equal to 0.000 (less than 0.05) confirming that regression model is significant. The results in the $95 \%$ Confidence Interval for B column reveal that with $95 \%$ confidence, when EMA increases by 1 unit, SSCM will increase from 1.001 to 1.037 units. The remaining two models are similarly explained which affirms positive relationships between sustainable supply chain management and 
financial efficiency, environmental efficiency. It means that when SSCM increases by 1 unit, financial efficiency and environmental efficiency increase by 1.161, 1.014 units respectively. In model 3, due to value of Sig. for constant is by 0.331 great than 0.05 , the coefficient does not add to the regression equation.

\section{Conclusions}

The results have indicated that EMA application significantly impacts on SSCM in construction materials manufacturing industry in Vietnam. It is believed that if enterprises adopt EMA practice, it is likely to efficiently implement SSCM. The result is matching with the outcome of Schaltegger (2013), Seuring \& Muller (2008), Burritt (2002), Burritt et al. (2011), Viere (2011) studies and confirm that EMA help enterprises in supply chain to comply environmental standards, reduce environmental risks, make sustainable decisions. According to Burritt et al. (2011), Viere (2011), EMA is a useful tool to gain more efficient design, production or logistical operations between partners in supply chain. Results have also shown that SSCM affects to financial and environmental efficiency. These findings are running are in line with some previous studies (e.g. Zhu, 2010; Green et al., 2012; Lai \& Wong, 2012; Mutingi, 2013) indicating there was a positive relationship between SSCM and financial and environmental performance. SSCM practices also have the ability to minimize environmental impacts while improving financial efficiency. The studies found that upgrading SSCM can help companies in supply chain to reduce waste, optimize resource usage, design friendly products and increase reputation (Green et al., 2012; Mutingi, 2013; Ochieng, 2016). Wu and Dunn (1995), Van Hoek (1999) determine that when enterprises use resources to produce desired goods and services, pollutants are produced at every stage of the supply chain process. Consequently, it is stressed the need for enterprises to target their environmental management efforts on the entire supply chain aimed at minimizing negative environmental impacts. On the other hand, Ochieng (2016) additionally proves that SSCM could be strongly identified with financial performance - reduce costs and improve profits.

From a practical perspective, the findings provide enterprises with a deeper understanding of how to achieve superior financial and environmental efficiency through implementing SSCM. Therefore, the government should re-examine the legal framework as well as give guidance's that may facilitate the implementation of EMA as well as SSCM. The government and enterprises should promote awareness of the advantages that SSCM through EMA can help enterprises improve eco-efficiency. The end result is all stakeholders such as all suppliers, manufacturers, distributors, customers and governments receive sustainable benefits. Finally, the study also promotes understanding about the link of the EMA application to SSCM and the relationship between SSCM and eco-efficiency in Vietnamese construction materials industry. SSCM is still the new management concept for most enterprises in this region where the level of SSCM implementation is low. Therefore, it is expected that the findings in the study can help to apply popularly SSCM into Vietnamese enterprises.

\section{Acknowledgement}

The authors would like to thank the anonymous referees for constructive comments on earlier version of this paper.

\section{References}

Baines, T., Brown, S., Benedettini, O., \& Ball, P. (2012). Examining green production and its role within the competitive strategy of manufacturers. Journal of Industrial Engineering and Management (JIEM), 5(1), 53-87.

Burritt, R. L., Hahn, T., \& Schaltegger, S. (2002). Towards a comprehensive framework for environmental management accounting-Links between business actors and environmental management accounting tools. Australian Accounting Review, 12(27), 39-50.

Boyd, D. E., Spekman, R. E., Kamauff, J. W., \& Werhane, P. (2007). Corporate social responsibility 
in global supply chains: a procedural justice perspective. Long Range Planning, 40(3), 341-356.

Burritt, R. L., Schaltegger, S., Bennett, M., Pohjola, T., \& Csutora, M. (Eds.). (2011). Environmental management accounting and supply chain management (Vol. 27). Springer Science \& Business Media.

Christ, K. (2017). Extending Environmental cost Accounting to the supply chain. International Federation of Accounting. https://www.ifac.org/global-knowledge-gateway/performance-financialmanagement/discussion/extending-environmental-cost

Earnhart, D., \& Lizal, L. (2010). The effect of corporate environmental performance on financial outcomes-profits, revenues and costs: Evidence from the Czech transition economy. Environmental \& Resource Economics, European Association of Environmental and Resource Economists, 46(3), $1-44$.

Mallery, P., \& George, D. (2003). SPSS for Windows step by step: a simple guide and reference. Allyn, Bacon, Boston.

Green Jr, K. W., Zelbst, P. J., Meacham, J., \& Bhadauria, V. S. (2012). Green supply chain management practices: impact on performance. Supply Chain Management: An International Journal, 17(3), 290-305.

Guide Jr, V. D. R., \& Srivastava, R. (1998). Inventory buffers in recoverable manufacturing. Journal of Operations Management, 16(5), 551-568.

Hart, S. L., \& Ahuja, G. (1996). Does it pay to be green? An empirical examination of the relationship between emission reduction and firm performance. Business strategy and the Environment, 5(1), 3037.

Hart, S.L. (1997). Beyond greening: Strategies for a sustainable world. Harvard Business Review, 75(1), 66-76.

Hyrslová, J., \& Hájek, M. (2005). Environmental management accounting in the framework of EMAS II in the Czech Republic. In Implementing Environmental Management Accounting: Status and Challenges (pp. 279-295). Springer, Dordrecht.

Iwata, H. \& Okada, K. (2010). How does environmental performance affect financial performance? Evidence from Japanese manufacturing firms. Munich Personal RePEc Archive Paper, No. 27721.

Jalaludin, D., Sulaiman, M. and Ahmad, N.N.N. (2011). Understanding environmental management accounting (EMA) adoption: A new institutional sociology perspective. Social Responsibility Journal, 7(4), 540-557.

Jamil, C. Z. M., Mohamed, R., Muhammad, F., \& Ali, A. (2015). Environmental management accounting practices in small medium manufacturing firms. Procedia-Social and Behavioral Sciences, 172, 619-626.

Jinadu, O., Agbeyangi, B. A., \& Mamidu, I. A. (2015). Impact of Environmental Management Accounting on Current Practices and Future Sustainability in South-West Nigerian Polytechnics. International Journal of Economics Commerce and Management, 3(10), 586-603.

Kokubu, K., \& Nashioka, E. (2005). Environmental management accounting practices in Japan. In Implementing environmental management accounting: Status and Challenges (pp. 321-342). Springer, Dordrecht.

Konar, S., \& Cohen, M. A. (2001). Does the market value environmental performance?. Review of Economics and Statistics, 83(2), 281-289.

Kreuze, J. G., \& Newell, G. E. (1994). ABC and life-cycle costing for environmental expenditures. Strategic Finance, 75(8), 38.

Lai, K. H., \& Wong, C. W. (2012). Green logistics management and performance: Some empirical evidence from Chinese manufacturing exporters. Omega, 40(3), 267-282.

Le, T., \& Nguyen, T. (2019). Practice environmental cost management accounting: The case of Vietnamese brick production companies. Management Science Letters, 9(1), 105-120.

Lee, S. M., Kim, S. T., \& Choi, D. (2012). Green supply chain management and organizational performance. Industrial Management \& Data Systems, 112(8),1148-1180.

Linton, J. D., Klassen, R., \& Jayaraman, V. (2007). Sustainable supply chains: An introduction. Journal of Operations Management, 25(6), 1075-1082. 
Mutingi, M. (2013). Developing green supply chain management strategies: A taxonomic approach. Journal of Industrial Engineering and Management (JIEM), 6(2), 525-546.

Ochieng, O.S., Awino, Z.B., Njihia, M.J., \& Iraki, W.N. (2016). Green supply chain management practices and performance of ISO 14001 certified manufacturing firms in East Africa. DBA Africa Management Review, 6(2), 103-128.

Ong, T., Teh, B. \& Ang, Y. (2014). The impact of environmental improvements on the financial performance of leading companies listed in Bursa Malaysia, International Journal of Trade, Economics and Finance, 5(5), 386-391.

Parker, L. D. (2000). Green strategy costing: Early days. Australian Accounting Review, 10(20), 4655.

Porter, M. E., \& van der Linde, C. (1995). Green and competitive. Harvard Business Review, 73(5), $120-134$

Qian, W. (2012). Revisiting the link between environmental performance and financial performance: who cares about private companies?. The $11^{\text {th }}$ ACSEAR conference, 2-4 December, Wollongong.

Ramli, A., \& Ismail, M. S. (2013). Environmental management accounting practices: A survey of ISO 14001 certified Malaysian organizations. Journal of Energy Technologies and Policy, 3(11), $415-$ 432.

Salomone, R. (2003). Life cycle assessment applied to coffee production: investigating environmental impacts to aid decision making for improvements at company level. Food, Agriculture and Environment, 1(2), 295-300.

Schaltegger, S. (2013). Accounting for eco-efficiency. In Environmental Management in Practice: Vol 1 (pp. 306-321). Routledge.

Schaltegger S. \& Burritt, R.L. (2000). Contemporary Environmental Accounting. Sheffield, Greenleaf Publishing.

Seuring, S., \& Müller, M. (2008). From a literature review to a conceptual framework for sustainable supply chain management. Journal of Cleaner Production, 16(15), 1699-1710.

Ten, E. (2005), Applying Stakeholder Theory to Analyze Corporate Environmental Performance: Evidence from Australia's Top 100 Listed Companies, Proceedings of the 2005 Accounting and Finance Association of Australia and New Zealand (AFAANZ) Annual Conference, Melbourne, Victoria, Australia, 03-05 July 2005.

Al-Tuwaijri, S. A., Christensen, T. E., \& Hughes Ii, K. E. (2004). The relations among environmental disclosure, environmental performance, and economic performance: a simultaneous equations approach. Accounting, Organizations and Society, 29(5-6), 447-471.

Van Hoek, R. I. (1999). From reversed logistics to green supply chains. Supply Chain Management: An International Journal, 4(3), 129-135.

Viere,T., Enden, J.V., \& Schaltegger, S. (2011). Life Cycle and Supply Chain Information in Environmental Management Accounting: A Coffee Case Study. Cited in Eco-Efficiency in Industry and Science, Volume 27. Springer Dordrecht Heidelberg London New York.

Vlachos, D., Georgiadis, P., \& Iakovou, E. (2007). A system dynamics model for dynamic capacity planning of remanufacturing in closed-loop supply chains. Computers \& Operations Research, 34(2), 367-394.

Wagner, M. (2005). Environmental performance and the quality of corporate environmental reports: The role of environmental management accounting. In Implementing environmental management accounting: Status and challenges (pp. 105-122). Springer, Dordrecht.

Wu, H. J., \& Dunn, S. C. (1995). Environmentally responsible logistics systems. International Journal of Physical Distribution \& Logistics Management, 25(2), 20-38.

Zailani, S., Jeyaraman, K., Vengadasan, G., \& Premkumar, R. (2012). Sustainable supply chain management (SSCM) in Malaysia: A survey. International Journal of Production Economics, 140(1), 330-340.

Zhu, Q., Geng, Y., \& Lai, K. H. (2010). Circular economy practices among Chinese manufacturers varying in environmental-oriented supply chain cooperation and the performance implications. Journal of Environmental Management, 91(6), 1324-1331. 
(C) 2020 by the authors; licensee Growing Science, Canada. This is an open access article distributed under the terms and conditions of the Creative Commons Attribution (CC-BY) license (http://creativecommons.org/licenses/by/4.0/). 